\title{
China's Environmental Protection in the New Era from the Perspective of Eco-civilization Construction
}

\author{
Ochrona środowiska w Chinach w dobie Nowej Ery \\ z perspektywy wdrażania Eko-cywilizacji
}

\author{
Qingzhi Huan
}

\author{
The Research Institute of Marxism, Peking University, China \\ E-mail:qzhuan@pku.edu.cn
}

\begin{abstract}
Under a particular context of China' eco-civilization construction in the New Era after the $18^{\text {th }}$ national congress of CPC, an interesting question is that the discourse of socialist eco-civilization and its practice can to what an extent reshape or change the relationship among eco-capital, green technology and public participation in achieving a better environmental governance. A field-study in Fuzhou City, Jiangxi Province, shows clearly that there are both great hope for a radical reconstruction and multitudinous difficulties and challenges in front of the pioneering Green enterprises and the pilot areas of eco-civilization construction.
\end{abstract}

Key words: eco-civilization construction, China, eco-capital, green technology, public participation

\section{Streszczenie}

W szczególnym momencie budowy eko-cywilizacji Chin w Nowej Erze po 18. kongresie narodowym KPCh interesującym jest, że koncepcja socjalistycznej eko-cywilizacji w praktyce może do pewnego stopnia przekształcić lub wręcz zmienić relacje pomiędzy eko-kapitałem, zieloną technologią i udziałem społeczeństwa w celu osiągnięcia lepszego zarządzania środowiskiem. Badanie przeprowadzone w mieście Fuzhou, w prowincji Jiangxi, wykazały, że wśród mieszkańców istnieje wielka nadzieja na radykalną przebudowę, zarazem jednak występuje mnogość trudności i wyzwań stojących przed pionierskimi zielonymi przedsiębiorstwami i pilotażowymi obszarami budowy eko-cywilizacji.

Słowa kluczowe: wdrażanie eko-cywilizacji, Chiny, eko-kapitał, zielona technologia, udział społeczny

\section{Introduction}

Owing to the arduous efforts of academia and the continuous promotion from practice over the past decade of 2008-2018, eco-civilization (shengtai wenming) or eco-civilization construction (shengtai wenming jianshe) in the context of contemporary China has largely established its status both as a policy system and an academic discourse (Huan, 2018a and 2018b; Huan, 2017a; Fang, 2014; Huan, Li and Lin, 2014; Liu, 2014 [2006]; Zhang, 2014; Lu, 2013; Wang and Yang, 2011; Yu, 2010; Chen, 2008; Wu, 2008; Ji, 2007), though there are still some difficulties or obstacles to make it to be internationally heard and recognized (Lord, 2018; Marinelli, 2018; Gare, 2016; Huan, 2016a; Magdoff, 2012 and 2011; Sal- leh, 2008; Morrison, 2007). As the core concept of an academic discourse, eco-civilization or eco-civilization construction is widely defined as an ecological negation and transcendence of modern industrial and urban civilization, and thus closely connecting with a new pattern of economic, social and cultural institutional framework as well as its corresponding perception basis. In other words, eco-civilization will definitely be a new civilization based on a new science of ecology rather than modern science and technology (Lu, 2013, p. 13). And as an emerging systematic theory of environmental politics and ecological culture, eco-civilization or eco-civilization construction can be expounded from three aspects or sub-dimensions (Huan, 2015a). Namely, it is a green-left ideological discourse on development of 
the governing political party (CPC), an environmental political-social theory insisting on a comprehensive transformation, or re-construction, of the contemporary society, and an organic way of thinking and philosophy with a strong link to the Chinese and/or Western Classical tradition.

Arguably, there are two inseparable levels or dimensions with the eco-civilization construction of China in the New Era after the $18^{\text {th }}$ national congress of Communist Party of China (CPC) which was held in $2012^{1}$. On the one hand, governments at all levels as well as the whole society should firmly establish and consciously carry out The socialist outlook on ecocivilization expounded clearly at the $19^{\text {th }}$ national congress of CPC in 2017 (Xi, 2017a, 2012) $)^{2}$, or to put it differently, leading or regulating the process of eco-civilization construction in China with a new socialist politics (Huan, 2014). On the other hand, more concrete policy initiatives or public policy instruments of environmental economy and environmental public administration should be introduced and applied, to push forward as soon as possible the modernization of China's ecological environmental governance system and governance capacity. In such a specific context, an interesting question is that the discourse of socialist eco-civilization and its practice in China can to what an extent reshape or change the relationship among eco-capital, green technology and public participation in reality.

\section{Two Clues of Theoretical Analysis}

Theoretically, there are at least two clues to be followed in analyzing the issue above. The first clue is the interaction of eco-capital, green technology and public participation. It should be noted that, eco-capital here mainly refers to certain new forms and scopes of natural ecosystem and its components to become economic resources and/or capitals, rather than those industrial and commercial natural resources and/or capitals in the traditional sense which are closely related to the exploitation, transportation and processing of natural resources (Li, 2018; Wei and Yang, 2018; Ye, 2015; Yin, 2015). Not only that, a more significant difference between eco-capital and traditional industrial and commercial natural capitals is that the former is to a certain degree based on our recognition of independent or unique value of natural eco-system and its elements. For instance, it should first of all include the economic value of repair (replacement) once one natural eco-system and its elements are contaminated or damaged. Thus,

\footnotetext{
${ }^{1}$ As for the accurate starting-point of New Era, a common understanding is the $18^{\text {th }}$ national congress of CPC in November 2012, at which Xi Jinping was elected as the top leader of CPC, though this term was first used in the working report to $19^{\text {th }}$ national congress of CPC in October 2017.
}

eco-capital targets at a better use and protection of natural eco-system and its elements. Similarly, the term green technology does not cover all the technological processes and means that are invented to deal with the natural eco-system and its elements. Rather, it mainly refers to the technological processes and means that are more environmentally friendly than traditional ones until their negative impacts on nature are zero (Guo, 2019; Yang, 2014). Thus, just like the case of eco-capital, green technology is also strongly relative or hierarchical. For example, we can distinguish them into different categories such as light green or dark green eco-capital and light green or dark green green technology. As for public participation, although it is supposed to include the participation of capital owners (such as state, communities and private capitalists) and research and development personnel (organizational units and individuals), here it more often than not refers to economic, social and political participation or involvements of the common people, directly or indirectly connected with the introduction and application of eco-capital and green technology (Hu, 2016; Shi and Chen, 2016; Wang, 2016).

Such a conceptual interpretation above is very important for us to correctly understand the relationship among eco-capital, green technology and public participation in the process of socialist eco-civilization construction of China. On the one hand, both ecocapital and green technology may to varying degrees affect production and life of the public of various sizes of societies (communities), and accordingly, they need to be examined and controlled democratically by the public who are affected and/or related. In other words, the specific forms of eco-capital and green technology are also the parts of production and life of the entire society, especially those concrete eco-capitals and green technologies associated with the field of mass consumption. On the other hand, the policy decision-making or choice capacity of the public for eco-capital and green technology is a significant indicator to test the eco-civilization level of Chinese society, and this is especially true for the characteristics of socialist eco-civilization. In another word, more authentic or higher degree of socialist eco-civilization means that the society as a whole will be more inclined to or more encourage the red-green versions of eco-capital and green technology, consciously combining the orientation of ecological environmental protection and the consideration of social justice.

\footnotetext{
${ }^{2}$ In the work report to the $18^{\text {th }}$ national congress of CPC in 2012, the accurate express is Striving for a new era of socialist eco-civilization. Of course, even after the $19^{\text {th }}$ national congress of CPC in 2017, the accuracy implications of socialist outlook on eco-civilization or socialist eco-civilization is still a controversial or even deliberately avoiding issue (Huan, 2018b and 2016a).
} 
What can be drawn from above analysis is that, different from the critical viewpoints of many ecoMarxists on eco-capital and green technology (Wallis, 2018; Sarkar, 1999), there may be a positive possibility in reality. That is to say, the creative introduction and application of eco-capital and green technology can act as a player of promoting public participation or involvement in the process of ecocivilization construction of China, especially considering its socialist institutional framework. The implicit logical mechanism can be summarized as follows. Democratic decision-making of governments at different levels and supervision action of the participatory public, directly (acting as the production operators and consumers) or indirectly (acting as the social members or citizens), can to a great degree determine the selection of pattern, application scope and consequence response of eco-capital and green technology, which will turn out to be the motivating reasons or social conditions to further encourage and promote the public participation or involvement.

The second analytical clue which can be followed is the interactive relationship among eco-capital, cultural capital and industrial capital. In my opinion, the term of Green development in the discursive context of contemporary China (Pan, 2019; Chen et al., 2018; Huan, Gao and Zhong, 2013), from the perspective of environmental economics or resource management, can be generalized as a proper disposal with the relationship among eco-capital, cultural capital and industrial capital. Green development is an umbrella term with quite broad implications and different usages. In most cases, it can be regarded as the synonym of sustainable development or environmentally friendly development in a general sense. Thus, it represents a certain degree of greening of the development discourse which has thus far have a much longer history, resulting in a less harmful ecological and environmental damage in the process of economic and social modernization development. Even in the discursive context of eco-civilization construction, there are at least three slightly different expressions for Green development. They are Three developments (san ge fazhan), Five new development concepts (wu ge xin fazhan linian) and Strategies (approaches) of eco-civilization construction (shengtai wenming jianshe zhanlue/lujing) (Huan, 2019). Three developments lay green development low carbon development and circular development side by side, mainly emphasizing the green or environmentally friendly characteristics of economic and/or industry (products) structure, while the latter two developments more refer to the features of low carbon emissions and the closed recycling of raw materials in the economic production process. Rather, what Green development as one of the Five new development concepts stresses is that consideration of eco-civilization or environmentally friendliness has become the guiding principle for China's social- ist modernization from overall planning to concrete practice, just like the roles of other four new development concepts of innovation, coordination, openness and sharing. By contrast, Green development as a strategy or practical approach of eco-civilization construction highlights the importance of improving China's eco-civilization construction level through gradually building green industrial and economic system, green energy supply system, green technical support system and green living consumption system. For the purpose of writing this article, the concept of Green development is mainly used in the third sense. More concretely, for improving the level of eco-civilization construction in China through the greening of economic system, energy system, technologic system and living and consumption styles, in the capital management point of view, there are at least two different approaches or tactics. They are either by utilizing the relatively strong industrial capital to support and cultivate eco-capital and cultural capital, or by taking advantages of the relatively rich ecological and cultural capitals to attract and accumulate industrial capital. For the former, I call it the Eco-modernization path, with Jiangsu Province and Guangdong Province as the actual examples; and for the latter, it is called Green development path, with Jiangxi Province and Fujian Province as the typical examples (Huan, 2017b; Huan, 2016b).

From the standpoint of eco-civilization and its construction, on the one hand, a higher or more fundamental objective for introducing eco-capital and cultural capital is to realize a more effective protection of natural ecosystems and cultural heritages. Although the exploitation and utilization of natural ecosystems and cultural and historical heritages as a specific resource should not be questioned or even denied, the top issue to be targeted at by introducing eco-capital and cultural capital is that they are better protected and inherited in the on-going process of modernization. In this regard, eco-capital and cultural capital have an obvious feature of virtual or instrumental capital, which cannot be simply regarded as industrial and commercial capital in the traditional sense, especially those forms shaped in the context of capitalist institutional relations and discourse (Brand and Wissen, 2014; Hawken et al., 1999). On the other hand, at least as far as the primary stage of socialism in China is concerned, the active role of traditional industrial and commercial capital cannot be simply negated, especially for those larger-scale administrative divisions or social communities (Xi, 2017b). A notable question in this regard is how to gradually weaken or replace the dominant economic evaluation standards/systems and improve the existing performance evaluation standards/systems of eco-civilization construction, such as the Green development index evaluation system formulated by National Bureau of Statistics and National Develop- 
ment and Reform Commission (NDRC) ${ }^{3}$. Arguably, current official evaluation systems of eco-civilization construction are still biased towards exploitation and utilization and social allocation of natural resources rather than on protection and restoration of natural ecosystems (Yan et al., 2016-2010; Qi, 2013).

Generally speaking, Green development approach (strategy) in a narrow sense is the most common model of eco-civilization construction in China today, especially in the various forms of demonstration zones, pioneer demonstration zones and pilot areas, trying to get started the dynamic process of eco-civilization construction with its relative rich eco-capital and/or cultural capital, for instance, the cases of Anji County, Zhejiang Province, and Kang County, Gansu Province (Huan, 2016c; Huan, 2015b). And admittedly, for those administrative jurisdictions or territories higher than county level, how to deal with traditional industrial and commercial capital is still a controversial and very difficult issue. At present, what we can safely say is that the political ideology of socialist outlook on eco-civilization and the national strategy of vigorously promoting eco-civilization construction of contemporary China have created a quite favourable societal environment, within which at least certain local pioneering areas can try and successfully achieve a relative balance and internal consistency of the three type of capitals in the reality (especially reflected in their industrial structure). Moreover, it seems that those administrative or geographic areas excessively concentrated in the traditional manufacturing industries and the related industries are confronting more difficulties and obstacles to starting such a green shift or transformation. Of course, it can be imaginable that, owing to having a relatively low level of economic modernization, it is absolutely not easy for them to handle the relationship among the three type of capitals above.

\section{The case of Fuzhou City, Jiangxi Province}

It is in the discursive context above that the exploratory practice of eco-civilization construction in $\mathrm{Fu}$ zhou city, Jiangxi Province, China, attracted our attention. On 26-29 April 2018, a research group mainly from Peking University and Donghua University of Technology, with the support of Rosa Luxemburg Foundation Beijing, conducted a field study on the theme of Eco-capital, green technology and public participation in the socialist eco-civilization construction at Fuzhou City, an eco-civilization pilot area of Jiangxi Province. Within the three days, we carried out on-the-spot investigations to the following four examples. They are 1) Runbang Agriculture at Dongxiang District, a privately-operated modern ecological production and management complex

\footnotetext{
${ }^{3}$ According to the national evaluation results bulletin of 2016 which is released in December 2017, the most deve-
}

which was once a state-run farm; 2) Feitianfeng Ecobreeding at Linchuan District, a private enterprise of organic poultry farming which began its business with renting the wasteland in the village at a low price; 3) The City Eco-cloud Data Information Platform (as well as the related Lübao Carbon GSP Public Service Platform), a recently hot technical innovation of public management based on the idea of attracting more people to know more about the environmental situation around them; 4) The Fenggang River Wetland, a successful reconstruction project of urban water ecological landscape, changed from a smelly foul water into an attractive landscape belt. What are in common among the four examples are the very high visibility and active interaction of ecocapital, green technology and public participation or involvement in the process of eco-civilization construction, as my Chinese colleagues have vividly described (Cai, 2018; Hua, 2018; Ju, 2018; Li, 2018). On this basis, we may further raise the following three questions regarding how these examples are broadening and deepening our understandings and/or expectations to the relationships of eco-capital, green technology and public participation and of eco-capital, cultural capital and industrial capital, from an eco-Marxist perspective, for instance.

Firstly, leading role of the local governments and its implementation mechanisms. Imaginably, local governments at different levels will play the role of a comprehensive organizer or guarantor in encouraging the development (inventing) of eco-capital and cultural capital, attracting societal industry and commerce capital into the field of eco-capital and cultural capital development and supporting the development, management and accumulation of these green capitals with favourable policies and administrative measures, just like what they have done in actively encouraging and promoting the development of township enterprises 40 years ago at the beginning of reform and opening up. But more noteworthily today, in what sense and through what ways should governments at different levels at the same time do well in the national (regional) policy and plan guidance in line with vigorously promoting the eco-civilization construction and as far as possible ensure or attract the institutionalized democratic participation of the people who are affected in this way or another. As for the policy and plan guidance, the most important thing is to integrate the national policies and strategies such as Eco-civilization Pilot Areas (shengtai wenming shiyanqu), Rural Revitalization (xiangcun zhenxing) and Beautiful Rural Construction (meili xiangcun jianshe), Construction of Small Towns (xiaochengzhen jianshe), Targeted Poverty Alleviation (jingzhun fupin) and so on, so as to achieve a comprehensive effect of policy. For the institutionalized democratic participation, the most

loped municipals or provinces such as Beijing, Fujian, Zhejiang, Shanghai and Chongqing come out in front. 
important thing is to try to extend the business or economic participation or involvement in a narrow sense(through investment and employment) into a social, economic and political participation or involvement as wide as possible.

Secondly, innovations of the systems and mechanisms promoting the eco-civilization construction and their extensibility and applicability. Undoubtedly, what is most to be expected from the above two interactive practices of capitals is whether and how they can bring about institutional and mechanism innovations of reconstruction in the process of vigorously promoting the eco-civilization construction in China. For the first time, the working report to the $19^{\text {th }}$ national congress of CPC clearly proposed that China will build an Ecological environmental governance system with governments as the major player, enterprises as the subject of liabilities, social organizations and the public as the co-participants (Xi, 2017a). Therefore, a more scientific environmental economic and environmental administrative public management of the above two interactive relations will certainly turn out to be an important methodological approach and great promoting power in creating a strong and effective ecological environmental governance system. Moreover, the practical exploration at the local levels will definitely be very diversified and vivid. Of course, in theory at least, we have to also consider the other one (or several) possibility. For instance, due to lacking of necessary or appropriate general social-economic conditions and regulation mechanism, the actual capitalization of ecological and/or cultural elements and its thriving economic development is eventually failed to become a green innovator or re-constructor of traditional industrial and commercial capital, instead to be just another form of the general capital (green capital), thus unable to play a preconceived role of promoting /safeguarding the ecological sustainability. Similarly, in terms of social sustainability, eco-capital or cultural capital is ultimately to be a driving force for further economic and social differentiation in local communities, rather than a practical path moving towards the beautiful future visions such as New Socialist Countryside (shehuizhuyi xin nongcun), Beautiful Country (meili xiangcun), New Type of Towns and Villages (xinxing chengzhenhua) and so on.

Thirdly, development of the model enterprises (communities) and their demonstration leading role. Enterprises and local communities are the constitutive social cells that practice and realize institutional or system innovations in the two interactive relations analyzed above. Moreover, in the discursive context of eco-civilization construction, they become more closely related. That is because, on the one hand, the development and application of eco-capital, cultural capital and green technology is inseparable from understanding and support of the surrounding and re- lated communities, due to the development of economic activities as such almost inevitably relates to the various natural ecological (cultural historical) resources and the urban and rural ecological environmental quality (cultural life) of the surrounding or affected areas and communities. Arguably, compared to the traditional industrial production and operation, the so-called Green economic activities are more directly related to natural eco-systems (cultural heritages) of the surrounding or affected areas and communities. On the other hand, the degree of civilization and the comprehensive development level of local communities will also have direct impacts on the development and application of eco-capital, cultural capital and green technology in the local areas, especially their selection of direction and specific forms. It can be expected that, the higher the overall quality and capacity of regulation and participation of local communities, the more likely the development and application of eco-capital, cultural capital and green technology presents itself as a higher level of ecological and social sustainability. Accordingly, the local society as a whole will more actively adopt the economic and technological forms with strong green or red green characteristics, and the enterprises will pay more attention to the governmental operation environmental regulations, their own green enterprise image and the ecological and social responsibilities in the process of production and operation. For that matter, besides their own rapid and healthy growth of the enterprises, all the institutional and policy innovations being conductive to a constructive interaction between enterprises and communities deserve our special attention.

Corresponding to the order of the three questions raised above, our major findings from the field-study in Fuzhou City, Jiangxi Province, can be briefly summarized as follows. First, party committees and governments at different levels and their subordinate departments are indeed putting the development of eco-capital, cultural capital and green technology at the unprecedented heights on their daily agenda, taking it as both a symbolistic measure and a practical approach in implementing the CPC's up-to-date political ideology and the national strategy of vigorously promoting eco-civilization construction. A good example of this is that, a deputy minister of Propaganda Department of municipal party committee is directly involved in the enterprise image promotion and product marketing of Feitianfeng Ecobreeding at Linchuan District, which is actually a private enterprise of organic poultry farming.

Secondly, both the development and application of The City Eco-cloud Data Information Platform as well as the related Lübao Carbon GSP Public Service Platform and the construction of The Fenggang River Wetland are achieving remarkable progress in attracting and safeguarding public participation or involvement in the eco-civilization construction. For 
instance, residents can get involved in the democratic supervision of local environmental quality and the following-up policy-making process through a form of daily life of earning green consumption points, which is based on the idea that your environmentally friendly behaviour of consumption will bring about you some free or cheaper commodities ${ }^{4}$. In just about half a year - from August 2017 to January 2018, the registered users of Lübao Carbon GSP Public Service Platform reached 162 000, 4\% of the total population of Fuzhou.

Third, the major efforts of improving the public service for and strengthening the economic administration of such emerging eco-agribusiness like Runbang Agriculture and Feitianfeng Eco-breeding associated with various forms of big data information platforms are showing tremendous potential for institutional innovation, going far beyond what they were originally defined or understood such as the issues of administrative law enforcement information disclosure and Three rural problems (san nong wenti). Rather, they put forward or point to a series of issues profoundly reforming the urban and rural public governance systems as well as their capacity building, such as the coordinated enforcement of informatization, specialization and democratization of urban ecological environmental management, the new dynamics and new paths of rural economic development and the new forms of realization of natural value. It is reasonable to believe that, all the new understandings to and properly dealing with these issues will to a large extent reshape our current knowledge of eco-civilization construction and the concept of eco-civilization itself. In short, the rapid rise of eco-agricultural enterprises (as the production and management complex) like Runbang Agriculture and Feitianfeng Eco-breeding provide us with an unpreceded richness of political imagination of the new pattern of agricultural economy and the new scene of rural life in the context of socialist eco-civilization construction, which can be to some extent regarded as an affirmation of my assumption about Green development approach (strategy) of the ecocivilization construction (Huan, 2017b).

Undoubtedly, there are lots of difficulties and challenges in front of the pioneering Green enterprises and the pilot areas of eco-civilization construction like Fuzhou City, Jiangxi Province (Cai, 2018; Ju, 2018; Li, 2018). Of them, to mainstream these Green enterprises as an enterprise and economic model, it will need a much longer time of their own efforts, together with some fundamental changes of the general social-economic system conditions (such as the national economic performance evaluation system), while their seemingly immature even naïve operat-

\footnotetext{
${ }^{4}$ Of course, from an ecologist perspective (Dobson 2003), it is not good or strong enough to make the common people to do the ecologically right things by attracting or tempting them to do so with more or less economic benefits. Ho-
}

ing environment (such as the relatively simple factory building and hardware facilities) and marketing strategies (such as the relatively weak consciousness of brand and its simplicity of publicity) today actually contains a very different direction of evolution in the future. Perhaps even more importantly, what pattern of relationship configuration with the surrounding communities (including residents) will Runbang Agriculture and Feitianfeng Eco-breeding - starting their business respectively from reconstructing an originally state-run farm and renting a wasteland in the village - evolve into eventually? Though, it is true that for the moment relationship between the two sides are relatively harmonious Runbang Agriculture hires a large number of residents from the local communities as its full-time or part-time workers, while Feitianfeng Eco-breeding takes up numerous villagers adjacent to it into its product business chain.

\section{Concluding remarks}

The major argument of this article is that, within an appropriate discursive and institutional system of socialist eco-civilization, introduction and application of eco-capital and green technology can turn out to be a promoting force of incorporating the local people into the emerging green industries or economy in China. Moreover, such a society (rather than capital or capitalists) oriented constructive interaction among them - eco-capital, green technology and public participation - may enhance or reshape the process of dealing with the various forms of environmental problem into a long journey moving towards a green future of eco-civilization. Of course, as the analysis of the case of Fuzhou City, Jiangxi Province, just one instance out of many in today's China, has clearly shown, there is no guarantee that this green development strategy or approach for eco-civilization construction is or will definitely be a success. Among the many affecting factors, the following two deserve our long-term observation and attention. Firstly, to what an extent and in what ways socialist political principles and institutional conditions can be better persisted and implemented in these pioneering areas of eco-civilization construction. A key question to be answered is that why these economically backward areas - according to conventional standards - are appropriate for practicing such socialist and/or ecologist ideals. Secondly, to what an extent and in what ways these pioneering areas for eco-civilization construction are allowed to operate their eco-capital and green technology along different principles or logics of economic management. As the case of Fuzhou City has shown us, the first round

wever, within a favourable societal environment and with necessary appropriate measures, these initial economic benefits-motivated behaviours might eventually become new living habits of the new generations. 
of eco-capital and green technology are often not from the local communities, instead from the developed areas like Shanghai, Beijing or Nanjing. Therefore, it would be very difficult for them to introduce and insist a new principle of enhancing ecological sustainability rather than making business as usual.

\section{References}

1. BRAND U., WISSEN M., 2014, The financialization of nature as crisis strategy, in: Journal für Entwicklungspolitik, 30(2), p. 16-45.

2. CAI H., 2018, Reflections of the ecologicalization mechanism of capital, in: Journal of Poyang Lake, 5, p. 58-62.

3. CHEN J. et al., 2018, Promoting Green Development and Realizing a Well-off Society in an All-round Way, China Forestry Press, Beijing.

4. CHEN X., 2008, On Eco-civilization, Chongqing Press, Chongqing.

5. DOBSON A., 2003, Citizenship and the Environment, Oxford University Press, Oxford.

6. FANG S., 2014, A Study of Marx's Environmental Thoughts and the Environment Friendly Society, Sanlian Publishing House, Shanghai.

7. GARE A., 2016, The Philosophical Foundations of Ecological Civilization: A Manifesto for the Future, Routledge Environmental Humanities, London

8. GUO J., 2019, Further improving the Jiangsu's innovation level of green technology, in: Xinhua Daily, 19 February.

9. HAWKEN P. LOVINS A., HUNTER LOVINS L., 1999, Natural Capitalism: Creating the Next Industrial Revolution,. Little, Brown and Company, New York.

10. HU L., 2016, A Study on the Public Participation in Eco-civilization Construction of Contemporary China, Huaqiao University, Quanzhou.

11. HUA Q., 2018, The Fuzhou Experience of socialist eco-civilization construction with Chinese characteristics, in: Theory and Review, 4, p. 52-56.

12. HUAN Q., 2019, The evolution of CPC's green modernization discourse since 40-year reform and opening up, in: The Journal of Yunmeng, 1.

13. HUAN Q., 2018a, The basic concepts concerning eco-civilization and its theories, in: Study with Socialism with Chinese Characteristics, 4, p. 16-26.

14. HUAN Q., 2018b, The triple visions of elaborating the socialist outlook on eco-civilization, in: Journal of Beijing Administrative Institute, 4, p. 63-70.

15. HUAN Q., 2017a, Construction of the eco-civilization demonstration areas from a three-dimensional perspective: Evaluation and prospect, in: Journal of China University of Geosciences, 3, p. 54-63.

16. HUAN Q., 2017b, The green development path for eco-civilization construction: A case of Jiangxi Province, in: Journal of Poyang Lake, 1, p. 29-41.

17. HUAN Q., 2016a, Socialist eco-civilization and social-ecological transformation, in: Capitalism Nature Socialism, 27/2, p. 51-66.

18. HUAN Q., 2016b, The eco-modernization path for eco-civilization demonstration province construction, in: Yuejiang Academic Journal, 8/6, p. 23-35.

19. HUAN Q., 2016c, The regional model of eco-civilization construction: A case of Anji County, in: Journal of Guizhou Provincial Party School, 4, p. 32-39.
20. HUAN Q., 2015a, The eco-civilization theory and its implications for green change, in: Marxism \& Realities, 5, p. 167-175.

21. HUAN Q., 2015b, Ecological industrialization, beautiful countryside and eco-civilization construction, in: China Ecological Civilization, 4, p. 64-68.

22. HUAN Q., 2014, New political vision 2.0 of eco-civilization, in: People's Tribune, Oct., p. 38-41.

23. HUAN Q., LI H., LIN Z., 2014, Ten Lectures on Ecocivilization Construction, The Commercial Press, Beijing.

24. JI Z. (ed.), 2007, On Eco-civilization, People's Press, Beijing.

25. JÜ C., 2018, The application of technology and the mechanism of public participation, in: Theory and Review, 4, p. 49-51.

26. LI Q., 2018, Public participation in the process of capital ecologicalization: Taking Fuzhou City as an example, in: Journal of Poyang Lake, 5, p. 52-57.

27. LIU S., 2014/2006, The Eco-Marxist Basic Principles of Economics, People's Press, Beijing.

28. LORD E., 2018, Building an Ecological Civilization across the Rural/urban Divide and the Politics of Environmental Knowledge Production in Contemporary China. University of Toronto, Toronto.

29. LU F., 2013, New Thoughts on Eco-civilization, China Science and Technology Press, Beijing.

30. MAGDOFF F., 2012, Harmony and ecological civilization: Beyond the capitalist alienation of nature, in: Monthly Review, 64/2, p. 1-9.

31. MAGDOFF F., 2011, Ecological civilization, in: Monthly Review, 62/8, p. 1-25.

32. MARINELLI M., 2018, How to build a 'Beautiful China' in the Anthropocene: The political discourse and the intellectual debate on ecological civilization, in: Journal of Chinese Political Science Online first https://doi.org/10.1007/s11366-018-9538-7.

33. MORRISON R., 2007, Building an ecological civilization, in: Social Anarchism: A Journal of Theory and Practice, 38.

34. PAN J., 2019, From ecological imbalance to eco-civilization: A transformative process of green development over 40 years of reform and opening-up, in: $U r$ ban and Environmental Studies, 4, p. 3-16.

35. QI X., 2013, A study of the eco-civilization construction evaluation index system, Ecological Economy, 12, p. 182-186.

36. SALLEH A., 2008, Eco-socialism and 'ecological civilization' in China, in: Capitalism Nature Socialism, 19/3, p. 122-128.

37. SARKAR S., 1999, Eco-Socialism or Eco-Capitalism, Zed Books, London.

38. SHI S., CHEN A., 2016, On public participation in eco-civilization of China, in: Economy of Forestry, 3, p. 25-29.

39. WANG Y., 2015, A Study on Public Participation in Eco-civilization Construction of China, Dalian University of Technology, Dalian.

40. WANG M., YANG Y., 2011, Theory and Practice of Socialist Eco-civilization Construction, People's Press, Beijing.

41. WALLIS V., 2018, Red-green Revolution: The Politics and Technology of Eco-socialism, Political Animal Press, Toronto.

42. WEI X., YANG L., 2018, Making the eco-capital to be flowing 'invaluable asset', in: Xinhua Daily, 4 December. 
43. WU F., 2008, Eco-civilization Construction: Theory and Practice, Central Compilation and Translation Press, Beijing.

44. XI J., 2017a, The Working Report to the $19^{\text {th }}$ congress of $C P C$, People's Press, Beijing.

45. XI J., 2017b, Discussion Excerpts on Socialist Ecocivilization Construction, Central Party Literature Press, Beijing.

46. XI J., 2012, The Working Report to the $18^{\text {th }}$ congress of $C P C$, People's Press, Beijing.

47. YAN G. et al., 2016-2010, Annual Report on China's Provincial Eco-civilization Index, Social Science Academic Press, Beijing.

48. YANG F., 2014, An Institutional Study on the Innovation of Green Technology: From a Perspective of
Eco-civilization, Party School of CPC Central Committee, Beijing.

49. YE W., 2015, Harmonious co-existence between human and nature depends the development of green capital, in: Economic Information Daily, $17 \mathrm{Au}-$ gust.

50. YIN H., 2015, Protecting natural ecological capital with the professional thinking and manner, in: Journal of the Chinese People's Political Consultative Conference, 12 November.

51. YU M., 2010, On Eco-civilization, Central Compilation and Translation Press, Beijing.

52. ZHANG Y., 2014, Eco-civilization from a Perspective of Historical Materialism, Renmin University of China Press, Beijing. 